\title{
Genetic stock composition of loggerhead turtles Caretta caretta bycaught in the pelagic waters of the North Atlantic
}

\author{
Erin L. LaCasella ${ }^{1, *}$, Sheryan P. Epperly ${ }^{2}$, Michael P. Jensen ${ }^{1}$, Lesley Stokes ${ }^{2}$, \\ Peter H. Dutton ${ }^{1}$
}

\begin{abstract}
${ }^{1}$ Marine Mammal \& Turtle Division, Southwest Fisheries Science Center, National Marine Fisheries Service, National Oceanic and Atmospheric Administration, 8901 La Jolla Shores Drive, La Jolla, California 92037, USA ${ }^{2}$ Southeast Fisheries Science Center, National Marine Fisheries Service, National Oceanic and Atmospheric Administration,
\end{abstract} 75 Virginia Beach Drive, Miami, Florida 33149, USA

\begin{abstract}
Sea turtle populations disperse widely across oceans and migrate between terrestrial nesting habitat and distant feeding and developmental habitats. Understanding population stock structure is important for accurately assessing threats such as mortality from fishery bycatch and for defining specific demographic units of conservation concern. We compared $775 \mathrm{bp}$ mtDNA control region haplotypes from 389 juvenile loggerhead turtles sampled as bycatch in the US pelagic longline fishery in the western North Atlantic Northeast Distant (NED) region to haplotype frequencies observed in 23 genetically distinct nesting stocks representing the 4 distinct population segments (DPSs) that have been identified throughout the Atlantic Ocean and Mediterranean Sea. We used Bayesian mixed-stock analysis to produce stock composition estimates for juvenile loggerhead turtles that use pelagic habitat in the central North Atlantic. We found that nearly all of the loggerheads caught in NED waters belonged to the Northwest Atlantic DPS $($ mean $=99.2 \%)$, with the majority coming from the large eastern Florida rookeries (mean = $84.0 \%$ ). We also detected contributions from the western Florida rookeries (mean $=11.7 \%$ ) and Mexico (mean $=3.5 \%$ ) but found little evidence of contributions from the rookeries of the South Atlantic, Northeast Atlantic, or Mediterranean DPSs. These results will help improve specific threat assessments and are relevant to ongoing development of conservation plans that are aligned to the recent DPS listings for loggerheads.
\end{abstract}

KEY WORDS: Mitochondrial DNA $\cdot$ Mixed stock analysis $\cdot$ Fisheries $\cdot$ Bycatch $\cdot$ Northeast Distant Longline Fishery

Resale or republication not permitted without written consent of the publisher

\section{INTRODUCTION}

The waters of the North Atlantic provide important foraging and breeding habitats as well as migratory routes for numerous marine species (e.g. bluefin tuna Thunnus thynnus, Galuardi \& Lutcavage 2012; right whales Eubalaena glacialis, Kenney et al. 2001; marine turtles Caretta caretta, Turtle Expert Working Group 2009 and Dermochelys coriacea, Turtle Expert Working Group 2007). Recogniz- ing life history strategies of various marine species and identifying links between the habitats used in time and space are crucial to building accurate population models and assessing the potential impacts to these populations (Taylor et al. 2010). Incidental capture (e.g. fisheries bycatch) is a source of injury and mortality for many marine species throughout the world's oceans (Baum et al. 2003, Lewison et al. 2004, Moore et al. 2009) and has been identified as a conservation priority for declining populations of 
endangered sea turtles (Wallace et al. 2008, 2011). The western North Atlantic, and in particular the productive Grand Banks, has historically been one of the richest fishing grounds in the world (Hutchings \& Myers 1995). Here, on the southern Grand Banks, the cold Labrador Current mixes with the warm eddies of the Gulf Stream, creating rich foraging habitats that attract marine species (Rice 2002). Longline fisheries typically operate throughout the tropical and temperate oceans, including Northeast Distant (NED) waters, which is a statistical reporting area of the North Atlantic designated by the US National Marine Fisheries Service (Cramer \& Adams 2000). The NED includes the Grand Banks and covers more than 5 million square kilometers of open ocean (Fig. 1) that encompasses important developmental habitats for North Atlantic loggerhead turtle Caretta caretta populations (Mansfield \& Putman 2013). The loggerhead is one of the most common incidentally caught sea turtle species in longline fisheries that operate within the NED (Witzell 1999, Foster et al. 2012).

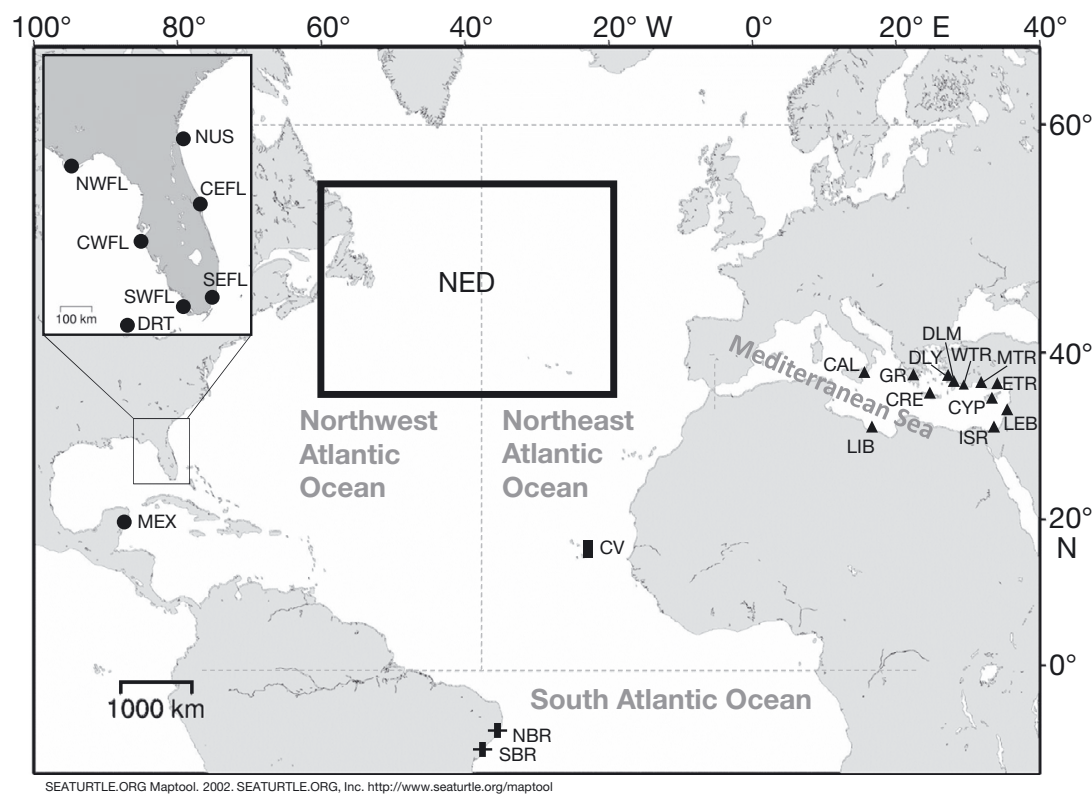

Fig. 1. Atlantic Ocean, indicating the Northeast Distant (NED) statistical zone, the 4 distinct population segments (DPSs), and the 23 source rookeries for loggerhead turtles in the Atlantic and Mediterranean that were used as the baseline dataset for the mixed stock analysis. Each rookery is indicated by a symbol, different for each DPS. The 23 source rookeries and their abbreviations are: northern US (NUS; includes North Carolina, South Carolina, Georgia, and northern Florida), central eastern Florida (CEFL), southeastern Florida (SEFL), southwestern Florida (SWFL), central western Florida (CWFL), northwestern Florida (NWFL), Dry Tortugas (DRT; includes Cay Sal Banks, Bahamas), Mexico (MEX), Cape Verde (CV), Greece (GR), eastern Turkey (ETR), middle Turkey (MTR), western Turkey (WTR), Dalaman, Turkey (DLM), Dalyan, Turkey (DLY), Cyprus (CYP), Lebanon (LEB), Crete (CRE), Israel (ISR), Calabria, Italy (CAL), Libya (LIB), north Brazil (NBR), and south Brazil (SBR)
Genetic studies have used maternally inherited mitochondrial DNA (mtDNA) markers to show that adult female loggerheads exhibit natal homing to nesting beach areas (Bowen et al. 1993, Carreras et al. 2007), resulting in various levels of genetic structuring among nesting populations, referred to as rookeries. These markers have been used to further determine the geographic extent of genetic connectivity among rookeries in order to identify management units (MUs) that recognize demographically solated rookeries or groups of rookeries, which are distinguished by haplotype frequency shifts (Moritz 1994). More recently there has been progress in dentifying distinct population segments (DPSs) that broader regional-scale structure that (Conant et al. 2009). Within the Atlantic, these were defined as the Northwest Atlantic, Northeast Atlantic, South Atlantic, and Mediterranean DPSs (Conant et al. 2009, USFWS \& NOAA 2011; our Fig. 1) and correspond to an analogous spatial grouping termed regional management units proposed by Wallace et al. (2010).

mtDNA markers have also been applied in mixed stock analysis (MSA) to determine the rookery origin of loggerhead turtles found in mixed foraging areas (e.g. Bowen et al. 2004, Reece et al. 2006), along migratory routes (e.g. Bowen et al. 1995), or in fisheries bycatch (e.g. Laurent et al. 1998, Carreras et al. 2011). These and other studies suggest that post-hatchling juveniles from beaches in the western North Atlantic generally move into oceanic developmental habitats, including, areas off the Grand Banks, the Azores, and Madeira, and throughout the Mediterranean (Bolten et al. 1998, Laurent et al. 1998, Carreras et al. 2006, Monzón-Argüello et al. 2009). An unknown proportion may move inside the North Atlantic gyre, entering its center (Mansfield \& Putman 2013). After about a decade, immature western Atlantic turtles migrate back across the Atlantic and settle in neritic and benthic environments along the 
eastern seaboard of North and Central America (Rankin-Baransky et al. 2001, Bowen et al. 2004, Reece et al. 2006) but may occasionally return to the open ocean or move across the ocean basin (Witzell 2002, McClellan \& Read 2007, Mansfield et al. 2009). However, some juveniles from neritic habitats shift back to the oceanic zone for several years, and others may never complete the transit across the gyre to the eastern Atlantic (Mansfield \& Putman 2013). Loggerhead turtles from Mediterranean rookeries, on the other hand, appear to stay within Mediterranean waters and rarely enter the Atlantic (Bolten et al. 1998, Laurent et al. 1998, Carreras et al. 2006, Revelles et al. 2007, Monzón-Argüello et al. 2009). Many of these studies focused on turtles in coastal foraging areas, and large information gaps still exist for the high seas pelagic regions in the North Atlantic, where it has been difficult to adequately sample loggerheads.

Furthermore, the studies mentioned above all used MSA to estimate the rookery origin of turtles from various foraging habitats. The performance of MSA relies heavily on the assumption that all (or at least the most significant) source rookeries have been adequately sampled. However, until recently, many gaps remained in the geographic coverage of sampled rookeries. Early studies defined 8 MUs for loggerhead turtles in the Atlantic and Mediterranean based on analysis of a $380 \mathrm{bp}$ portion of the mtDNA control region: Greece and Turkey in the Mediterranean; Bahia in Brazil; Quintana Roo in Mexico; Dry Tortugas off the Florida Peninsula, USA; northwest Florida, USA; south Florida, USA; and northeast Florida to North Carolina, USA (Encalada et al. 1998, Laurent et al. 1998, Bowen et al. 2004). The latter MU encompasses a large stretch of disconnected nesting habitats in northeast Florida, Georgia, South Carolina, and North Carolina. More recently, studies have further resolved the genetic structure among southeastern USA rookeries and have identified additional MUs in central eastern and southeastern Florida (2011, Shamblin et al. 2012), while previously unsampled rookeries have been characterized in Cape Verde (Monzón-Argüello et al. 2010), the Mediterranean (Garofalo et al. 2009, Yilmaz et al. 2011, Saied et al. 2012, Clusa et al. 2013), and Brazil (Reis et al. 2010), and sampling has been supplemented for Quintana Roo and Cozumel, Mexico (Shamblin et al. 2012). In combination, these studies now provide a much more comprehensive rookery coverage representing $23 \mathrm{MUs}$ in the Atlantic and Mediterranean that may be used as a baseline dataset of potential source stocks for more comprehensive MSA.
Here we used mtDNA sequence data and Bayesian statistical approaches to estimate the stock composition of loggerhead turtles encountered in the NED by the US pelagic longline fishery. This study incorporates newly available rookery data (Garofalo et al. 2009, Monzón-Argüello et al. 2010, Reis et al. 2010, Saied et al. 2012, Shamblin et al. 2012, Clusa et al. 2013) to identify the loggerhead stocks that use oceanic habitats in the North Atlantic. Loggerheads are the first species under the US Endangered Species Act to have designated DPSs. This provides a relevant framework to address the contributions represented in the NED bycatch, as these distant rookeries are likely to be impacted by threats in this foraging region.

\section{MATERIALS AND METHODS}

\section{Sample collection}

Loggerhead turtles captured incidentally in the NED by the US pelagic longline fleet were sampled between 2000 and 2008. Once the turtles were brought on board, fishery observers measured straight (SCL) and curved carapace lengths and width when possible. All turtles were tagged with a passive integrated transponder tag and/or an inconel flipper tag and were released alive. Skin biopsies were collected from the rear flippers of captured turtles using a $6 \mathrm{~mm}$ biopsy punch (Acuderm) based on the methods described in Stokes \& Epperly (2008). Tissue samples were stored in $2 \mathrm{ml}$ cryovials in a saltsaturated dimethyl sulfoxide (DMSO) solution or a salt-saturated MilliQ $\mathrm{H}_{2} \mathrm{O}$ solution and archived and maintained at $-20^{\circ} \mathrm{C}$ in the Southwest Fisheries Science Center (SWFSC) Marine Mammal and Turtle Molecular Research Sample Collection in La Jolla, California.

\section{Genetic analyses}

Genomic DNA was isolated from all samples using standard manufacturer protocols for 1 of 4 extraction processes: phenol chloroform (modified from Sambrook et al. 1989), sodium chloride (modified from Miller et al. 1988), a modified DNEasy ${ }^{\circledR}$ Qiagen extraction kit, or an X-tractor Gene robot (Corbett Robotics). The control region of the mitochondrial genome was amplified using polymerase chain reaction (PCR) methodologies to obtain 800 bp using primers LCM-15382 (5' GCT TAA CCC TAA AGC 
ATT GG $3^{\prime}$ ) and H950g (5' GTC TCG GAT TTA GGG GTT TG 3') (Abreu-Grobois et al. 2006). Samples were amplified in a $25 \mu \mathrm{l}$ PCR reaction and were carried out on MJ Research or Bio Rad PTC-100s or Applied Biosystems ${ }^{\circledR} 2720$ thermocyclers. The PCR cycling parameters were as follows: initial 2 min DNA denaturation at $90^{\circ} \mathrm{C}$, followed by 35 cycles of (1) $50 \mathrm{~s}$ denaturation at $94^{\circ} \mathrm{C}$, (2) $50 \mathrm{~s}$ annealing between 52 and $56^{\circ} \mathrm{C}$, and (3) $1 \mathrm{~min}$ extension at $72^{\circ} \mathrm{C}$, with a final 5 min extension at $72^{\circ} \mathrm{C}$. Negative controls were used in each PCR to detect any contamination. The PCR products were confirmed visually on $2 \%$ agarose gels stained with ethidium bromide (Maniatis et al. 1982). Purification of PCR products was done using a Qiaquick PCR Purification kit (Qiagen) or by combining $5 \mu \mathrm{l}$ of PCR product with $2 \mu \mathrm{l}$ of an Exonuclease I and Shrimp Alkaline Phosphatase solution (USB). Both strands were cycle sequenced using an $\mathrm{ABI}^{\circledR}$ Big Dye Terminator v3.1 or v3.1 ABI Prism Terminator Cycle Sequencing Kit and analyzed with Applied Biosystems ${ }^{\circledR}$ (models 3130 and 3730 ) automated genetic analyzers. Sequences were aligned, edited, and cropped at a standard cropping site (Frey et al. 2009) of $775 \mathrm{bp}$ using the program SeqScape v2.5 (Applied Biosystems ${ }^{\circledR}$ ). Haplotypes were designated by comparing the generated sequences to a reference library of short $380 \mathrm{bp}$ and long $775 \mathrm{bp}$ haplotypes representing published loggerheads from the Atlantic and Mediterranean, using the standardized nomenclature of the Archie Carr Center for Sea Turtle Research (http://accstr.ufl.edu/resources/mtdna-sequences/).

\section{Statistical analysis}

The program BAYES (Pella \& Masuda 2001) was used to estimate contributions from 23 known MUs for turtles incidentally caught by the US pelagic longline fishery in the NED. The analysis was conducted using 2 different models. One model used equal prior probabilities (flat priors) for all parameters (source MUs), and in the second model the potential contributions of different MUs to the bycatch samples were weighted relative to the size of the MU (population size priors, Bass et al. 2004). Using weighted priors may be beneficial when genetic differentiation is weak, shared haplotypes occur between the source populations, or when there are large differences in population size. However, it is important to note that such a model relies on the assumptions being correct and biologically meaningful. In this model, there is an assumption that larger MUs contribute more individuals to the mixture than smaller MUs (Bolten et al. 1998).
A total of 20000 Markov Chain Monte Carlo steps were run for 23 chains. Each chain was started at different starting points of 0.91 for $1 \mathrm{MU}$ and 0.005 for the other 22 MUs. A burn-in of 10000 runs was used to calculate the posterior distribution. The Gelman and Rubin shrink factor diagnostic was computed to ensure that all chains had converged, as was indicated by a shrink factor of less than 1.2 for each chain (Pella \& Masuda 2001). Individuals with haplotypes that had not been previously observed in any of the MUs (known as 'orphan' haplotypes) were removed from the analysis by the program as these are noninformative; however, they may indicate new MUs not yet sampled or undersampling of MUs.

Published data from 23 source MUs that have been identified to date, which combine into 4 DPSs, were used to estimate the proportions of each MU that were represented in the NED bycatch (Garofalo et al. 2009, Monzón-Argüello et al. 2010, Reis et al. 2010, Yilmaz et al. 2011, Saied et al. 2012, Shamblin et al. 2012, Clusa et al. 2013): (1) Northwest Atlantic DPS: northern USA (NUS; includes North and South Carolina, Georgia, and northern Florida), central eastern Florida (CEFL), southeastern Florida (SEFL), southwestern Florida (SWFL), central western Florida (CWFL), northwestern Florida (NWFL), Dry Tortugas (DRT; includes Cay Sal Bank Bahamas), Mexico (MEX); (2) South Atlantic DPS (based on 380 bp haplotypes): north Brazil (NBR), south Brazil (SBR); (3) Northeast Atlantic DPS: Cape Verde (CV); and (4) Mediterranean DPS: Greece (GR), eastern Turkey (ETR), middle Turkey (MTR), western Turkey (WTR), Dalaman, Turkey (DLM), Dalyan, Turkey (DLY), Cyprus (CYP), Lebanon (LEB), Crete (CRE), Israel (ISR), Calabria, Italy (CAL), and Libya (LIB) (Table 1). We are not including the Cuban MU in the Northwest Atlantic or Tunisia in the Mediterranean as there are no published data for longer haplotypes. The size of the nesting population for each MU in the USA was calculated as the average annual nest counts for 2002 to 2006 in Florida and South Carolina and 2006 to 2011 in North Carolina and Georgia (unpubl. data from: Florida Fish and Wildlife Conservation Commission, South Carolina Department of Natural Resources, North Carolina Wildlife Resource Commission, and Georgia Department of Natural Resources), additional nesting population sizes represent the annual average number of nests and were obtained from Marcovaldi \& Chaloupka (2007) (Brazil), Casale \& Margaritoulis (2010) (Mediterranean), and Monzón-Argüello et al. (2010) (Cape Verde and Mexico). To test for differences in haplotype frequencies among years within the NED samples, we 
first performed a global test of differentiation using $F_{\mathrm{ST}}$ and the Fisher's exact test (Raymond \& Rousset 1995) as implemented in Arlequin 3.5 (Excoffier \& Lischer 2010). Pairwise comparisons were then conducted between all pairs of years.

\section{RESULTS}

\section{Genetic analysis}

Sequence data from 389 individual turtles (SCL ranged from 35.0 to $72.0 \mathrm{~cm}$, mean $=56.7 \mathrm{~cm}$ ) were generated from the NED bycatch. Fifteen unique haplotypes were detected based on shorter alignments, and corresponded to 22 haplotypes based on the increased sequence length. Haplotypes originally described by 380 bp were subdivided into additional variants when using $775 \mathrm{bp}$ sequences, if differences were discovered outside of the shorter reading frame (e.g. CC-A1 further differentiated to CC-A1.1, CCA1.2, etc.) as done in previous studies using this extended fragment (Garofalo et al. 2009, MonzónArgüello et al. 2010, Yilmaz et al. 2011, Shamblin et al. 2012, Saied et al. 2012, Clusa et al. 2013). Nineteen of these haplotypes are found within the 23 rookeries described above and in Table 1. Haplotypes CC-A2.10, CC-A15.1, and CC-A49.1, each only found in a single individual, have not yet been reported from nesting beaches surveyed in previous studies. These 3 haplotypes are considered 'orphan' haplotypes and were excluded from further analysis. Of the haplotypes with a known origin, CC-A1.1 and CC-A2.1 were the most common ones found among the NED bycatch (42.4 and 36.5\%, respectively). CCA1.1 is common but only found in US rookeries, while CC-A1.3 and CC-A1.4 are found in most US rookeries, Mexico, and Cape Verde. CC-A2.1 is the most geographically widespread haplotype and is present in all of the western Atlantic, eastern Atlantic, and Mediterranean rookeries, except for those in Brazil. Variants CC-A2.3 through CC-A2.5 have only been identified in a few NW Atlantic rookeries at low frequencies. CC-A3.1 has been identified in the majority of NW Atlantic rookeries and in Turkey, Lebanon, and Libya in the Mediterranean, and was observed in $3.6 \%$ of the NED bycatch samples. CCA4 is fixed in Brazil and has not been identified in any other MU; however, it was found in 1 NED sample. Although Brazil only has short haplotype data, the region has so far been included in the MSA because of the unique haplotypes only found there. CC-A10.1 is found in $1.3 \%$ of the NED samples and has been identified in many of the NW Atlantic rookeries. Note that the short haplotype, CC-A10, has previously been reported for 1 sample in Greece (Laurent et al. 1998); however, it has not been identified in any of the more comprehensive studies for that $\mathrm{MU}$, including the longer sequence baseline dataset used in our analysis. CC-A13.1 has been identified in a few of the NW Atlantic rookeries and in middle Turkey in low frequencies. CC-A20.1, which to date has only been discovered in Calabria, Italy, in the Mediterranean and in central eastern and southern Florida, was identified in $1.8 \%$ of our samples. The remaining haplotypes observed in the NED have only been identified within the Northwest Atlantic DPS (Table 1).

\section{Statistical analysis}

The global test of differentiation among years for the NED bycatch samples was not significant $\left(F_{\mathrm{ST}}=\right.$ $-0.008, p=0.867$; Fisher's exact test $\mathrm{p}=0.976$ ) and no significant differences between years were detected in the pairwise comparisons $(p>0.05$, results not shown). We therefore pooled the results for the subsequent MSA (Table 2).

The MSA indicated that the NED loggerhead bycatch is primarily composed of animals from Florida rookeries in the Northwest Atlantic DPS (Fig. 2). With uniform priors, the combined southeastern Florida and central eastern Florida MUs made up the majority of the stock composition (68.9\%) with a $21.1 \%$ contribution from western Florida MUs (SWFL, CWFL, NWFL, and DRT). The estimated contribution from the Mexican MU was small (mean $4.5 \%$; CI: $0.0-10.3 \%$ ). It is uncertain to what degree the NUS rookeries contributed, as the proportion estimated for that MU was less than $1 \%(0.6 \%$; CI: $0.0-7.0 \%)$. The combined contributions from all Mediterranean rookeries were estimated to be $5.0 \%$, indicating possible small contributions from Calabria $(2.2 \%$; CI: $0.0-7.9 \%)$ and middle Turkey $(0.6 \%$; CI: 0.0-6.9\%); however, the other Mediterranean MUs each had mean estimates of $\leq 0.5 \%$ (Fig. 2). The contribution to the NED bycatch from the south Atlantic was inconclusive, with very low mean estimates for Brazil $(0.2 \%$; CI: $0.0-0.6 \%)$, and there was no compelling evidence of contribution from Cape Verde in the Northeast Atlantic $(0.0 \%$; CI: $0.0-0.3 \%)$.

When using rookery size as a prior, the combined estimates from southeastern Florida and central eastern Florida made up the majority of the stock composition at $83.2 \%$ (Fig. 2). This proportion was expected 


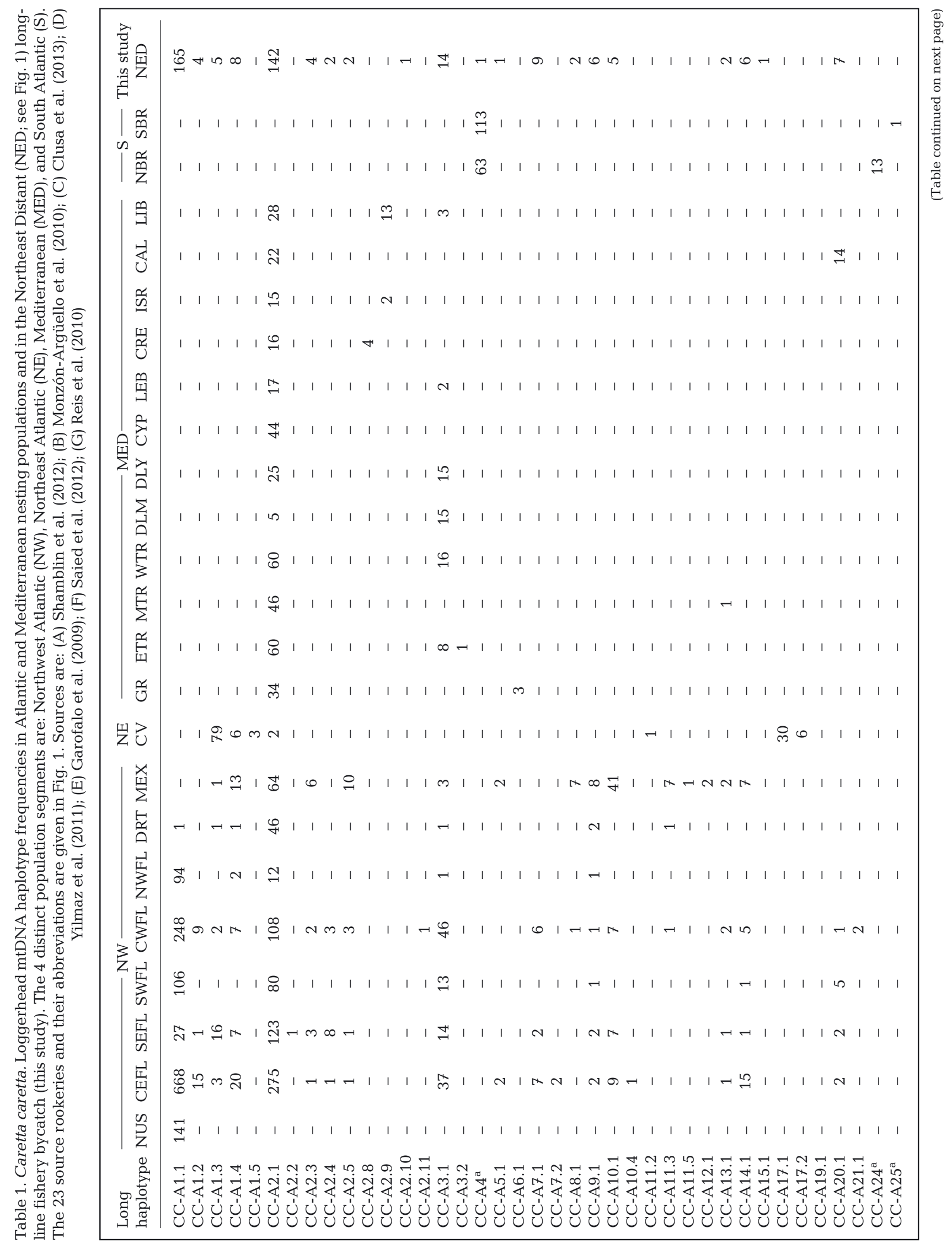




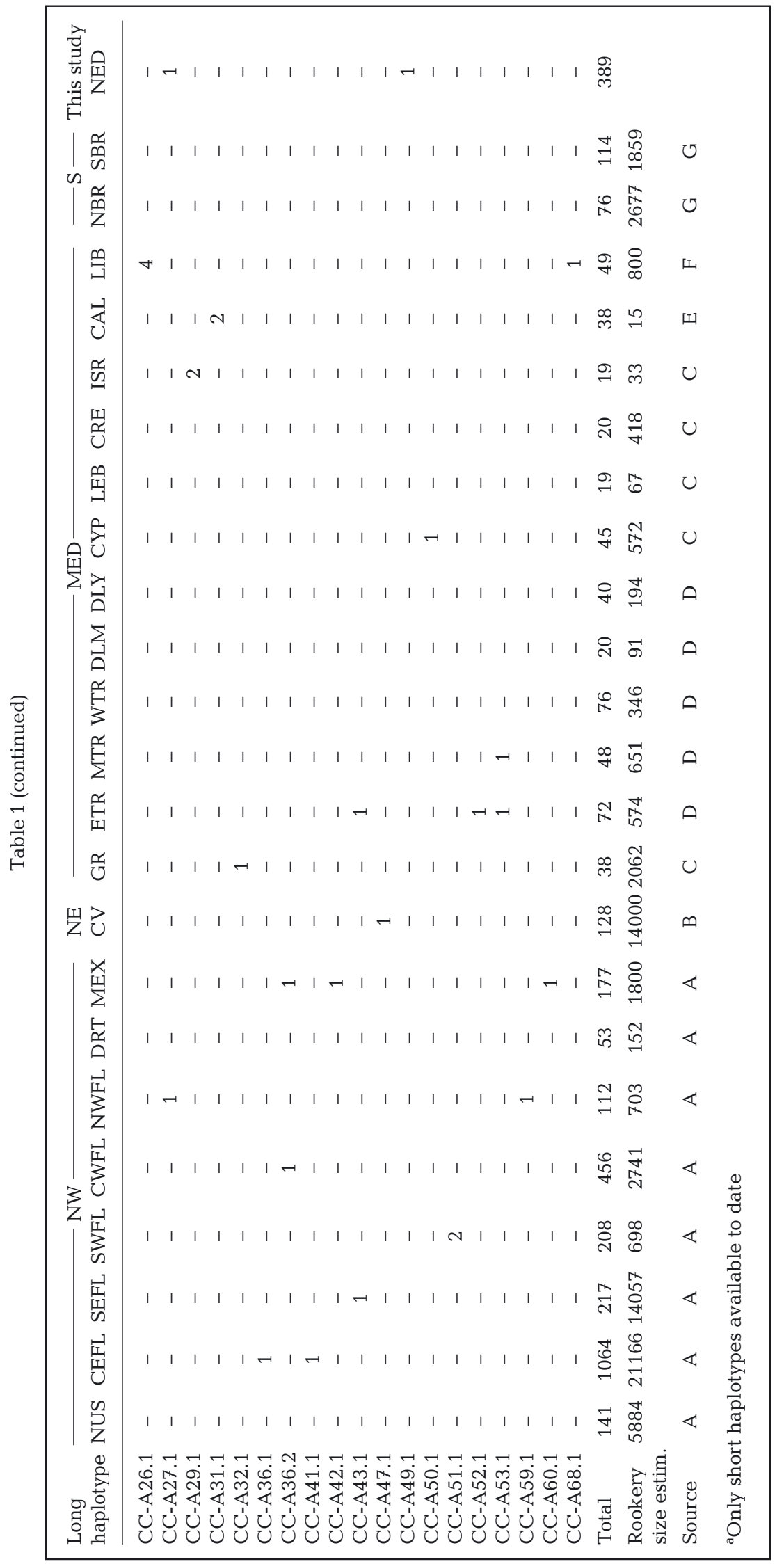

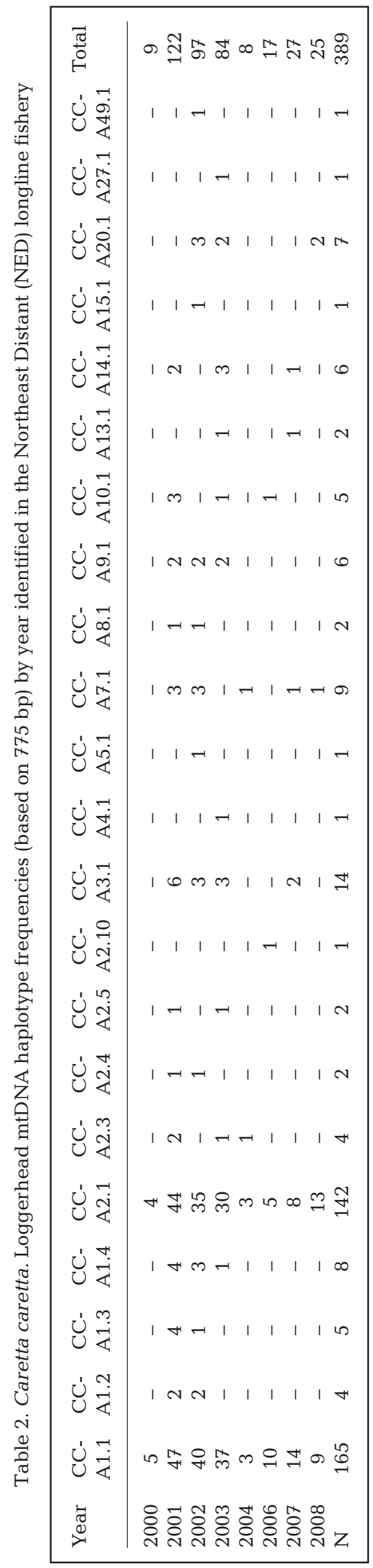




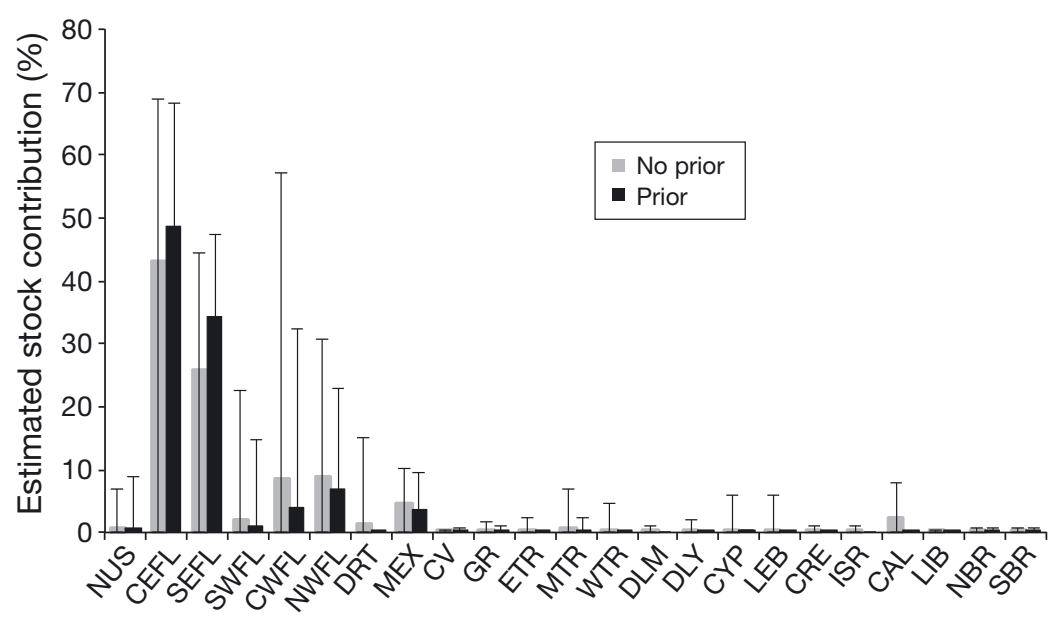

Fig. 2. Caretta caretta. Estimated mixed stock analysis (MSA) stock contributions from Atlantic and Mediterranean rookeries using weighted rookery size (dark grey) and flat (light grey) priors. Confidence intervals (95\%) are indicated. The 23 source rookeries and their abbreviations are given in Fig. 1

to be high, as rookeries in the CEFL and SEFL MUs are many orders of magnitude larger than most of the other US rookeries. The bycatch comprised a mean of $11.7 \%$ contribution from the western Florida MUs (SWFL, CWFL, NWFL, and DRT), and the NUS MU also contributed minimally $(0.8 \%$, CI: $0.0-8.8 \%)$. The Mexican MU likely contributed only a small proportion, with an estimated mean of $3.5 \%$ (CI: $0.0-9.4 \%$ ). The Cape Verde and Brazilian MUs remained unlikely sources, with mean estimates of $0.1 \%$ each. When using priors, the MUs of the Mediterranean DPS were unlikely to be a source, with a combined estimated mean of only $0.4 \%$ (Fig. 2). Greece, Cyprus, and middle Turkey were the only Mediterranean MUs detected in the NED samples, with a mean of $0.1,0.1$, and $0.2 \%$, respectively. The Mediterranean estimates were significantly lower when rookery size was taken into account (Fig. 2).

\section{DISCUSSION}

Our study provides new estimates of the relative nesting stock contributions for loggerhead turtles caught incidentally by the US pelagic longline fishery within the NED and provides insights into the stock distribution of juvenile loggerheads within North Atlantic pelagic habitats. Overall, the results between the 2 models (flat or weighted priors) were similar. However, the use of flat priors generated larger confidence intervals around the estimates, especially for small and distant rookeries such as those in the Mediterranean. This is partly a result of a common haplo- type (CC-A2.1) that is shared across the Atlantic Ocean. However, a number of studies have shown that the composition of loggerheads in oceanic feeding areas is roughly proportional to the size of the source rookeries (Bolten et al. 1998, Bowen \& Karl 2007) and the use of rookery size as a prior is biologically meaningful for this loggerhead foraging aggregation. Compared to the very large Florida rookeries, those in the Mediterranean are relatively small. For instance, there are only 12 to 20 nests reported each year at Calabria (Italy), the only Mediterranean location identified in the NED where haplotype CCA20.1 is found (Garofalo et al. 2009). When population size is accounted for, contributions from MUs with those smaller rookeries approach 0 , and the uncertainty surrounding the point estimates are reduced for greater confidence. We therefore focus the discussion on the results from using weighted priors in the MSA, since they are more likely to be biologically meaningful (Bass et al. 2004).

Our results demonstrate that immature loggerheads in the central North Atlantic are almost exclusively of Northwest Atlantic DPS origin (mean = $99.2 \%$ ), with the majority coming from the eastern Florida rookeries $($ mean $=84.0 \%)$. We also detected contributions from the western Florida rookeries $($ mean $=11.7 \%)$ and Mexico $($ mean $=3.5 \%)$ but found little evidence to suggest any significant contributions from the rookeries of the South Atlantic, Northeast Atlantic, or Mediterranean DPSs. The finding of a major contribution from the Florida rookeries is consistent with other MSA studies in North Atlantic foraging loggerhead populations. In the Azores and Madeira, $\sim 90 \%$ of the foraging turtles were estimated to come from eastern Florida rookeries, and all $(100 \%)$ originated from western Atlantic rookeries (Bolten et al. 1998). MonzónArgüello et al. (2009) concluded that the majority (80 to $91 \%$ ) of eastern Atlantic juveniles found on the foraging grounds of the Canary Islands, Andalusia, Madeira, and the Azores were likely of northwestern Atlantic origins. These studies also concluded that haplotypes known exclusively from Mediterranean rookeries are absent in Atlantic waters (Revelles et al. 2007, Monzón-Argüello et al. 2009).

Juvenile turtles from Cape Verde rookeries disperse into the Atlantic and may be found in the foraging grounds of Madeira, the Azores, and the Canary 
Islands as well as in Mediterranean waters (MonzónArgüello et al. 2010). The latter study assigned a large percentage of these turtles to 'unknown' foraging areas using the many-to-many MSA, a rookerycentric method that estimates the destination and origin of individuals in a metapopulation. In the present study, however, there was no evidence of Cape Verde turtles in the NED, and turtles from Cape Verde likely forage in unsampled locations across the western and southern Atlantic (Monzón-Argüello et al. 2010). The absence of contribution from the large Cape Verde rookeries illustrates the role that distance and ocean currents (e.g. the Canary Current and the Equatorial Counter Current) play in barriers to dispersal into the NED region.

Interestingly, Monzón-Argüello et al. (2009) found some evidence of latitudinal stock segregation by oceanic juveniles sampled as strandings on islands in the Northeast Atlantic (Azores, Madeira and Canary Islands), suggesting additional complexity to factors influencing stock mixes in ocean juveniles that warrant further study. Considering the spatial scale of our dataset, we are certain that a combination of variables including rookery size, distance to rookeries, and ocean currents all influence the stock contribution estimates identified in the NED fishery bycatch. Whereas larger post-oceanic stage juveniles in the Northwest Atlantic appear to segregate spatially, presumably as a result of behavioral factors, to neritic foraging grounds in the vicinity of their natal rookeries (Bowen et al. 2004), the stock composition of the oceanic juveniles in our study appears to be largely influenced by the oceanographic features of the Gulf Stream and North Atlantic Gyre which primarily transport post-hatchlings into the NED area from the Northwest DPS rookeries, with relative proportions generally corresponding to rookery size and to some extent, distance. Point values provided here should be used as estimates rather than precise measures, as there are some limitations to MSA.

Normally, the presence of orphan haplotypes found on foraging grounds highlights the problem of insufficient sampling of potential source rookeries (Jensen et al. 2013), emphasizing the need for more comprehensive sampling of rookeries. However, in our study we found only 3 individuals with orphan haplotypes ( $<0.8 \%$ of all samples), which suggests comprehensive sampling of source rookeries. Furthermore, expanding the mtDNA sequence length from 380 to $775 \mathrm{bp}$ increased the resolution of the genetic marker and proved to be useful to identify variability within common haplotypes (Monzón-Argüello et al. 2010, Shamblin et al. 2012, present study). The additional resolution has tightened and improved confidence intervals, and as a result increased the power of the MSA to yield more robust stock contribution estimates. The use of nuclear markers in combination with mtDNA can also considerably improve confidence and power in MSA studies (Carreras et al. 2011). This information has provided the impetus for establishing the Atlantic and Mediterranean Loggerhead Genetics Expert Working Group to re-assess the loggerhead mtDNA baseline data for the Atlantic and Mediterranean and thus help further define stock boundaries for future MSA. While use of longer sequences has improved the ability to characterize finescale stock structure at the MU level, our focus in this study is the broader DPS scale. Based on our MSA results we conclude that loggerheads in the central North Atlantic are almost exclusively of Northwest Atlantic DPS origin.

Overall, our results fit the model of hatchlings dispersing from their natal beaches in Florida and being transported by ocean currents into the North Atlantic gyre system (Carr 1986, Bolten et al. 1998). These small juvenile turtles target convergence zones and develop further in the oceanic waters of the North Atlantic and in foraging grounds such as the NED/ Grand Banks, Azores, Madeira, and the Canary Islands along the African coast and even in the western Mediterranean (Carr 1986, Bolten et al. 1998, Laurent et al. 1998, Carreras et al. 2006, Revelles et al. 2007, Carreras et al. 2011), although some leave the gyre system and go into the gyre center (Mansfield \& Putman 2013). Putman et al. (2010) recently suggested that as distance to the major current system increases, nest density decreases; thus the large rookeries along the southeastern USA have greater hatchling survivorship and greater numbers of returning females due to the proximity to favorable ocean currents (e.g. Gulf Stream System). We found that the rookery MSA components represented in the NED fishery were roughly proportional to rookery size, with the exception of very distant rookeries (e.g. Cape Verde), suggesting that smaller populations are not being disproportionately impacted by fishery bycatch while in the NED. Nevertheless, any take of animals from MUs made up of small rookeries is of particular concern (Turtle Expert Working Group 2009, Richards et al. 2011), as those MUs are especially vulnerable to extirpation, assuming there is no movement of females among the MUs. These small rookeries in some cases contribute to genetic diversity of the DPS, and while the turtles from these MUs might represent only a small proportion of the fisheries bycatch, their loss would be significant to the 
MU. Lastly, it is unlikely that those rookeries would be re-colonized during time frames associated with sea turtle management. Additional longer sequence datasets from multiple fisheries representing the entire distribution of foraging areas and life history stages will allow use of rookery-centric many-tomany analysis (Bolker et al. 2007) for a more comprehensive assessment of cumulative threats to any given MU. This is an area of future international collaboration being promoted by the Atlantic and Mediterranean Loggerhead Genetics Expert Working Group.

Loggerhead turtles face numerous anthropogenic threats throughout the world's oceans, and knowledge of connectivity between rookeries and foraging areas in the high seas is required to properly and efficiently manage populations of this highly migratory species. Collaborative conservation and management efforts among nations are crucial in the protection and the recovery of depleted sea turtle populations (Gilman et al. 2006). With this study, we have demonstrated that MSA is useful for evaluating the potential impacts of fisheries to regional nesting populations. Our results will help improve stock-specific threat assessments and are relevant to ongoing development of conservation plans that are aligned to the recent DPS listings for loggerheads.

Acknowledgements. We thank the NOAA Pelagic Observer Program, Fisheries Research Institute, Blue Water Fisherman's Association, L. Belskis, and M. Argyropoulou for collecting or processing samples. Genetic analysis was funded by the NOAA Fisheries Service and carried out at SWFSC La Jolla Laboratory by the Marine Turtle Genetics Program. We also thank S. Roden, A. Frey, V. Pease, M. Averbeck, A. Lanci, G. Serra-Valente and A. Bowman for helping with sample processing. We acknowledge A. Bolten, K. Bjorndal, B. Shamblin, A. Abreu-Grobois, L. Soares, C. MonzónArgüello, C. Carreras, O. Turkozan, J. Thoft Nielsen, M. Clusa, J. Nairn, and L. Cardona of the Atlantic and Mediterranean Loggerhead Genetic Expert Working Group that provided a forum for stimulating discussion on issues related to stock structure analysis. We also thank A. Abreu-Grobois, J. Bohnsack, B. Perrin, K. Stewart, R. LeRoux, and 3 anonymous reviewers for reviewing, editing, and improving the quality of this manuscript. Samples were collected under ESA Section 10(a)(1)(A) permits issued by NMFS to the Southeast Fisheries Science Center (nos. 1260, 1324, 1429, and 1552), and samples were imported from the high seas under the authority of CITES (no. US045532/9) and Designated Port Exception Permits (no. LE046715-0) issued by the USFWS.

\section{LITERATURE CITED}

Abreu-Grobois FA, Horrocks JA, Formia A, Dutton PH and others (2006) New mtDNA D-loop primers which work for a variety of marine turtle species may increase the resolution of mixed stock analysis. In: Frick M, Panagopoulou A, Rees AF, Williams K (compilers) 26th Annu Symp Sea Turtle Biol Conserv. International Sea Turtle Society, Athens, p 179

$>$ Bass AL, Epperly SP, Braun-McNeill J (2004) Multi-year analysis of stock composition of a loggerhead turtle (Caretta caretta) foraging habitat using maximum likelihood and Bayesian methods. Conserv Genet 5:783-796

> Baum JK, Myers RA, Kehler DG, Worm B, Harley SJ, Doherty PA (2003) Collapse and conservation of shark populations in the Northwest Atlantic. Science 299: 389-392

Bolker BM, Okayama T, Bjorndal KA, Bolten AB (2007) Incorporating multiple mixed stocks in mixed stock analysis: 'many-to-many' analyses. Mol Ecol 16:685-695

Bolten AB, Bjorndal KA, Martins HR, Dellinger T, Biscoito MJ, Encalada SE, Bowen BW (1998) Transatlantic developmental migrations of loggerhead sea turtles demonstrated by mtDNA sequence analysis. Ecol Appl 8:1-7

> Bowen BW, Karl SA (2007) Population genetics and phylogeography of sea turtles. Mol Ecol 16:4886-4907

> Bowen BW, Avise JC, Richardson JI, Meylan AB, Margaritoulis D, Hopkins-Murphy SR (1993) Population structure of loggerhead turtles (Caretta caretta) in the Northwestern Atlantic Ocean and Mediterranean Sea. Conserv Biol $7: 834-844$

Bowen BW, Abreu-Grobois FA, Balazs GH, Kamezaki N, Limpus CJ, Ferl RJ (1995) Trans-Pacific migrations of the loggerhead turtle (Caretta caretta) demonstrated with mitochondrial DNA markers. Proc Natl Acad Sci USA 92: 3731-3734

Bowen BW, Bass AL, Chow SM, Bostrom M and others (2004) Natal homing in juvenile loggerhead turtles (Caretta caretta). Mol Ecol 13:3797-3808

> Carr AF (1986) Rips, FADS, and little loggerheads. Bioscience 36:92-100

> Carreras C, Pont S, Maffucci F, Pascual M and others (2006) Genetic structuring of immature loggerhead sea turtles (Caretta caretta) in the Mediterranean Sea reflects water circulation patterns. Mar Biol 149:1269-1279

- Carreras C, Pascual M, Cardona L, Aguilar A and others (2007) The genetic structure of the loggerhead sea turtle (Caretta caretta) in the Mediterranean as revealed by nuclear and mitochondrial DNA and its conservation implications. Conserv Genet 8:761-775

- Carreras C, Pascual M, Cardona L, Marco A and others (2011) Living together but remaining apart: Atlantic and Mediterranean loggerhead sea turtles (Caretta caretta) in shared feeding grounds. J Hered 102:666-677

Casale P, Margaritoulis D (2010) Sea turtles in the Mediterranean: distribution, threats and conservation policies. IUCN, Gland

> Clusa M, Carreras C, Pascual M, Demetropoulos A and others (2013) Mitochondrial DNA reveals Pleistocenic colonisation of the Mediterranean by loggerhead turtles (Caretta caretta). J Exp Mar Biol Ecol 439:15-24

Conant TA, Dutton PH, Eguchi T, Epperly SP and others (2009) Loggerhead sea turtle (Caretta caretta) 2009 status review under the US Endangered Species Act. Report of the biological review team to the National Marine Fisheries Service, August 2009. NOAA Fisheries, Office of Protected Resources, Silver Spring, MD

Cramer J, Adams H (2000) Large pelagic logbook newsletter: 1998. NOAA Tech Memo NOAA Fisheries-SEFSC433. NOAA, Miami, FL 
Encalada SE, Bjorndal KA, Bolten AB, Zurita JC and others (1998) Population structure of loggerhead turtle (Caretta caretta) nesting colonies in the Atlantic and Mediterranean as inferred from mitochondrial DNA control region sequences. Mar Biol 130:567-575

Excoffier L, Lischer H (2010) Arlequin suite ver 3.5: a new series of programs to perform population genetics analyses under Linux and Windows. Mol Ecol Resour 10: 564-567

Foster DG, Epperly SP, Shah AK, Watson JW (2012) Evaluation of hook and bait type on the catch rates in the western North Atlantic Ocean pelagic longline fishery. Bull Mar Sci 88:529-545

Frey A, Dutton P, LaCasella E, LeRoux R, Abreu-Grobois A (2009) Standardizing the mtDNA control region fragment for sea turtles: How long do sequences need to be? In: Belskis L, Frick M, Panagopoulou A, Rees AF, Williams K (comps) Proc 29th Annu Symp Sea Turtle Biol Conserv. NOAA Tech Memo NOAA NMFSSEFSC-630. NOAA, Miami, FL

Galuardi B, Lutcavage M (2012) Dispersal routes and habitat utilization of juvenile Atlantic bluefin tuna, Thunnus thynnus, tracked with mini PSAT and archival tags. PLoS ONE 7:e37829

Garofalo L, Mingozzi T, Micò A, Novelletto A (2009) Loggerhead turtle (Caretta caretta) matrilines in the Mediterranean: further evidence of genetic diversity and connectivity. Mar Biol 156:2085-2095

Gilman EL, Zollett E, Beverly S, Nakano H and others (2006) Reducing sea turtle by-catch in pelagic longline fisheries. Fish Fish 7:2-23

Hutchings JA, Myers RA (1995) The biological collapse of Atlantic cod off Newfoundland and Labrador. In: Arnason R, Felt L (eds) The North Atlantic fisheries: successes, failures, and challenges. Island Studies Press, Charlottetown, p 37-94

Jensen MP, FitzSimmons NN, Dutton PH (2013) Molecular genetics of sea turtles. In: Musick J, Lohman K, Wyneken J (eds) The biology of sea turtles, Vol III. CRC Press, Boca Raton, FL

Kenney RD, Mayo CA, Winn HE (2001) Migration and foraging strategies at varying spatial scales in western North Atlantic right whales : a review of hypotheses. J Cetacean Res Manag 2(Spec Issue):251-260

> Laurent L, Casale P, Bradai MN, Godley BJ and others (1998) Molecular resolution of marine turtle stock composition in fishery bycatch: a case study in the Mediterranean. Mol Ecol 7:1529-1542

Lewison RL, Crowder LB, Read AJ, Freeman SA (2004) Understanding impacts of fisheries bycatch on marine megafauna. Trends Ecol Evol 19:598-604

Maniatis T, Fritsch E, Sambrook J (1982) Molecular cloning: a laboratory manual. Cold Spring Harbor Laboratory Press, Woodbury, NY

Mansfield KL, Putman NF (2013) Oceanic habits and habitats Caretta caretta. In: Musick J, Lohman K, Wyneken J (eds) The biology of sea turtles, Vol III. CRC Press, Boca Raton, FL, p 189-211

Mansfield KL, Saba VS, Keinath J, Musick J (2009) Satellite tracking reveals a dichotomy in migration strategies among juvenile loggerhead turtles in the Northwest Atlantic. Mar Biol 156:2555-2570

Marcovaldi MÂ, Chaloupka M (2007) Conservation status of the loggerhead sea turtle in Brazil: an encouraging outlook. Endang Species Res 3:133-143
McClellan CM, Read AJ (2007) Complexity and variation in loggerhead sea turtle life history. Biol Lett 3:592-594

Miller SA, Dykes DD, Polesky HF (1988) A simple salting out procedure for extracting DNA from human nucleated cells. Nucleic Acids Res 16:1215

Monzón-Argüello C, Rico C, Carreras C, Calabuig P, Marco A, López-Jurado LF (2009) Variation in spatial distribution of juvenile loggerhead turtles in the eastern Atlantic and western Mediterranean Sea. J Exp Mar Biol Ecol 373:79-86

Monzón-Argüello C, Rico C, Naro-Maciel E, Varo-Cruz N, López P, Marco A, López-Jurado LF (2010) Population structure and conservation implications for the loggerhead sea turtle of the Cape Verde Islands. Conserv Genet 11:1871-1884

Moore JE, Wallace BP, Lewison RL, Zydelis R, Cox TM, Crowder LB (2009) A review of marine mammal, sea turtle and seabird bycatch in USA fisheries and the role of policy in shaping management. Mar Policy 33: 435-451

Moritz C (1994) Defining 'evolutionarily significant units' for conservation. Trends Ecol Evol 9:373-375

Pella J, Masuda M (2001) Bayesian methods for analysis of stock mixtures from genetic characters. Fish Bull 99: 151-167

Putman NF, Bane JM, Lohmann KJ (2010) Sea turtle nesting distributions and oceanographic constraints on hatchling migration. Proc R Soc Lond B Biol Sci 277:3631-3637

Rankin-Baransky K, Williams CJ, Bass AL, Bowen BW, Spotila JR (2001) Origin of loggerhead turtles stranded in the northeastern United States as determined by mitochondrial DNA analysis. J Herpetol 35:638-646

Raymond M, Rousset F (1995) An exact test for population differentiation. Evolution 49:1280-1283

> Reece JS, Ehrhart LM, Parkinson CL (2006) Mixed stock analysis of juvenile loggerheads (Caretta caretta) in Indian River Lagoon, Florida: implications for conservation planning. Conserv Genet 7:345-352

Reis EC, Soares LS, Vargas SM, Santos FR and others (2010) Genetic composition, population structure and phylogeography of the loggerhead sea turtle: colonization hypothesis for the Brazilian rookeries. Conserv Genet 11: 1467-1477

Revelles M, Carreras C, Cardona L, Marco A and others (2007) Evidence for an asymmetrical size exchange of loggerhead sea turtles between the Mediterranean and the Atlantic through the Straits of Gibraltar. J Exp Mar Biol Ecol 349:261-271

Rice J (2002) Changes to the large marine ecosystem of Newfoundland-Labrador shelf. In: Sherman K, Skjoldal HS (eds) Large marine ecosystems of the North Atlantic. Changing states and sustainability. Elsevier, Amsterdam, p 51-104

Richards PM, Epperly SP, Heppell SS, King RT and others (2011) Sea turtle population estimates incorporating uncertainty: a new approach applied to western North Atlantic loggerheads Caretta caretta. Endang Species Res 15:151-158

Saied A, Maffucci F, Hochscheid S, Dryag S and others (2012) Loggerhead turtles nesting in Libya: an important management unit for the Mediterranean stock. Mar Ecol Prog Ser 450:207-218

Sambrook J, Fritsch EF, Maniatis T (1989) Molecular cloning: a laboratory manual. Cold Spring Harbor Laboratory Press, Cold Spring Harbor, NY 
Shamblin BM, Dodd MG, Bagley DA, Ehrhart LM and others (2011) Genetic structure of the southeastern United States loggerhead turtle nesting aggregation: evidence of additional structure within the peninsular Florida recovery unit. Mar Biol 158:571-587

Shamblin BM, Bolten AB, Bjorndal KA, Dutton PH and others (2012) Expanded mitochondrial control region sequences increase resolution of stock structure among North Atlantic loggerhead turtle rookeries. Mar Ecol Prog Ser 469:145-160

Stokes L, Epperly S (eds) (2008) Sea turtle research techniques manual. NOAA Tech Memo NMFS-SEFSC-579. National Marine Fisheries Service Southeast Fisheries Science Center, Miami, FL

Taylor BL, Martien K, Morin P (2010) Identifying units to conserve using genetic data. In: Boyd IL, Bowen WD, Iverson SJ (eds) Marine mammal ecology and conservation - a handbook of techniques. Oxford University Press, Oxford, p 306-324

Turtle Expert Working Group (2007) An assessment of the leatherback turtle population in the Atlantic Ocean. NOAA Tech Memo NMFS SEFSC-555. NOAA, Miami, FL

Turtle Expert Working Group (2009) An assessment of the loggerhead turtle population in the western north Atlantic Ocean. NOAA Tech Memo NMFS SEFSC-575. NOAA, Miami, FL

USFWS (US Fish and Wildlife Service), NOAA (National Oceanic and Atmospheric Administration) (1996) Policy regarding the recognition of distinct vertebrate popula-

Editorial responsibility: Paolo Casale,

Rome, Italy tion segments under the Endangered Species Act. Fed Regist 61:4722-4725

USFWS, NOAA (2011) Endangered and threatened species; determination of nine distinct population segments of loggerhead sea turtles as endangered or threatened. Fed Regist 76:58868-58952

Wallace BP, Heppell SS, Lewison RL, Kelez S, Crowder LB (2008) Impacts of fisheries bycatch on loggerhead turtles worldwide inferred from reproductive value analysis. J Appl Ecol 45:1076-1085

Wallace BP, DiMatteo AD, Hurley BJ, Finkbeiner EM and others (2010) Regional management units for marine turtles: a novel framework for prioritizing conservation and research across multiple scales. PLoS ONE 5:e15465

Wallace BP, DiMatteo AD, Bolten AB, Chaloupka M and others (2011) Global conservation priorities for marine turtles. PLoS ONE 6:e24510

Waples S (1995) Evolutionarily significant units and the conservation of biological diversity under the Endangered Species Act. Am Fish Soc Symp 17:8-27

Witzell WN (1999) Distribution and relative abundance of sea turtles caught incidentally by the U.S. pelagic longline fleet in the western North Atlantic Ocean, 19921995. Fish Bull 97:200-211

Witzell WN (2002) Immature Atlantic loggerhead turtles (Caretta caretta): suggested changes to the life history model. Herpetol Rev 33:266-269

Yilmaz C, Türkozan O, Bardakci F (2011) Genetic structure of loggerhead turtle (Caretta caretta) populations in Turkey. Biochem Syst Ecol 39:266-276

Submitted: February 12, 2013; Accepted: August 6, 2013 Proofs received from author(s): October 25, 2013 